\title{
PENGARUH TERAPI MUSIK TRADISIONAL CINA TERHADAP KESEPIAN PADA LANSIA DI PANTI JOMPO YAYASAN GUNA BUDI BAKTI KELURAHAN MARTUBUNG KECAMATAN MEDAN LABUHAN KOTA MEDAN TAHUN 2019
}

\author{
Arlis ${ }^{1}$, Windy Viktorina Bate' $\mathbf{e}^{2}$ \\ ${ }^{1}$ Institute Kesehatan Sumatera Utara $;^{2}$ Institute Kesehatan Sumatera Utara \\ Email:arlisarlis67@gmail.com
}

\begin{abstract}
Loneliness in the elderly is a common thing where they feel feelings of isolation, exclusion, lack of attention from those around them, isolated from others. Traditional music is ethnic music originating from each region and even tribe, this music has a regular rhythm so that it can create relaxation and optimal resting conditions. This study used the Quasi Experiment Design with the onegroup pre and post test design method. The purpose of this study was to determine the effect of traditional Chinese music therapy on loneliness in the elderly. The population in this study amounted to 70 people with a sample of 41 people using Purposive Sampling techniques. Data collection uses the Ucla Loneliness Scale Version 3 questionnaire. The results of the Paired Sample T-Test statistic obtained p-value 0,000 $<0.05$, which means that there is an influence of traditional Chinese music therapy on loneliness in the elderly. Based on the results of these studies, traditional Chinese music therapy can be used as an alternative to reduce loneliness.
\end{abstract}

\section{Keywords: Traditional Chinese Music Therapy, Loneliness, Elderly}

\section{PENDAHULUAN}

Lanjut usia adalah kelompok manusia yang berusia 60 tahun ke atas (Sunaryo, 2016). Menua adalah proses yang dimulai sejak lahir dan umum dialami oleh semua makhluk hidup dimana penuaan dapat dilihat dari tiga perspektif, yaitu usia biologis, usia psikologis dan usia sosial.

Data Biro sensus Amerika Serikat meperkirakan Indonesia bakal mengalami pertambahan warga lanjut usia terbesar di seluruh dunia pada tahun 1990 - 2025, yaitu sebesar 414\%. Data Dinas Kependudukan Amerika Serikat (1999), jumlah populasi lanjut usia yang berusia $\geq 60$ tahun diperkirakan hampir mencapai 600 juta orang dan diprediksikan menjadi 2 milyar di tahun 2050. Saat ini di Indonesia ada 23,9 juta orang tergolong lansia. Dari data yang diperoleh di Kementerian Sosial, 3 juta (tepatnya 2,9 juta jiwa) di antaranya terlantar. Indonesia merupakan negara ke-lima yang memilki lansia terbesar di dunia. Pada tahun 1990 jumlah lansia sekitar 12,7 juta jiwa (6,29 persen) dan tahun 2000 mencapai 14,4 juta $(7,18$ persen). Tahun 2020 diperkirakan menjadi 28,8 juta jiwa atau 11,34 persen dari total penduduk Indonesia (Sunaryo, 2016). Populasi lansia di Provinsi 
Sumatera Utara memiliki presentase sebesar $10,42 \%$ merupakan provinsi yang memiliki jumlah lansia terbesar ke 5 setelah DI Yogyakarta, Jawa Tengah, Jawa Timur, dan Bali (Kemenkes RI, 2017). Jadi setiap tahunnya, lansia di Indonesia mengalami peningkatan yang signifikan.

Masalah lain yang sering terjadi pada lansia yaitu kehilangan, kemiskinan, tidak diterima/ditolak, belum menemukan makna hidup, ketergantungan perasaan, tidak berdaya dan mudah menyerah, takut terhadap kematian, sedih karena kematian orang lain, kemunduran fisik dan mental, depresi, dan rasa penyesalan mengenai hal-hal yang lampau (Sunaryo, 2016). Kesepian merupakan kondisi yang sering mengancam kehidupan para lansia ketika anggota keluarga hidup terpisah dari lansia, kehilangan pasangan hidup, kehilangan teman sebaya, dan ketidakberdayaan untuk hidup mandiri (Gunarsa, 2009).

Johnson et al., (1993) dalam National Council on Ageing and Older People (2004), melaporkan bahwa prevalensi lansia di Amerika yang mengalami kesepian menunjukkan angka yang cukup tinggi sebanyak $62 \%$ lansia (Fitriana, 2013). Di Indonesia, penelitian yang dilakukan Ikasi, dkk (2014) di Kelurahan Limbungan Rumbai Pesisir Riau menunjukkan hasil kesepian berat
42 responden $(56,0 \%)$, kesepian rendah 33 responden $(44,0 \%)$. Penelitian yang dilakukan oleh Lestari (2014) di Padukuhantiwir Sumber Sari Moyudan Sleman Yogyakarta menunjukkan hasil bahwa sebagian besar lansia berada pada kesepian rendah sebesar 24 responden $(57,1 \%)$, kesepian sedang sebanyak 11 responden $(26,2 \%)$ dan kesepian berat sebanyak 7 responden (16,7\%). Hasil penelitian tersebut menunjukkan bahwa sebagian besar lansia mengalami kesepian, dari kesepian ringan hingga kesepian berat.

Kesepian yang terjadi pada lansia yang merupakan masalah psikologis yang dapat dilihat dari: a) berkurangnya kegiatan mengasuh anak-anak; b) berkurangnya teman akibat kurangnya aktivitas diluar rumah; c) berkurangnya aktivitas sehingga waktu kosong bertambah banyak; d) meninggalnya pasangan hidup; e) ditinggalkan anak karena menempuh pendidikan yang lebih tinggi, atau untuk bekerja; f) anak telah dewasa dan membentuk keluarga sendiri. Seseorang yang mengatakan bahwa dirinya kesepian biasanya menilai dirinya sebagai seseorang yang tidak berharga, tidak diperhatikan dan tidak dicintai (Septiningsih\&Na'imah, 2012). Kesepian yang sering terjadi di panti jompo adalah kesepian situasional, dimana kesepian situasional ini terjadi ketika seseorang kehilangan integrasi 
sosial atau komunitas yang terdapat teman dan hubungan sosial (Sears dkk, 2009)

Dampak kesepian yang dialami oleh lansia biasanya menyebabkan berbagai masalah seperti depresi, keinginan bunuh diri, sistem kekebalan tubuh menurun, gangguan tidur, kecemasan, ketidakbahagiaan dan ketidakpuasan yang diasosiasikan dengan pesimisme, self-blame, rasa malu bahkan menyebabkan kematian (Khairani, 2014; Nuraini dkk, 2018).

Salah satu cara untuk mengatasi kesepian menurut Nursing Interventions Classification yang terdapat dalam domain perilaku, kelas terapi perilaku, intervensi 4400 (Bulechek dkk, 2016) yaitu terapi musik, dimana aktivitas yang dilakukan yaitu: 1) definisikan perubahan spesifik perilaku dan fisiologi seperti yang diinginkan (misalnya relaksasi, stimulasi, konsentrasi, dan pengurangan nyeri); 2) pertimbangkan minat klien pada musik; 3) identifikasi musik yang dikuasai klien; 4) informasikan individu mengenai tujuan pengalaman terhadap musik; 5) pilih musik - musik tertentu yang mewakili musik yang dikuasai klien; 6) bantu individu untuk posisi yang nyaman; 7) batasi stimuli eksternal selama mendengarkan musik; 8) buatlah kaset/cakram optik dan peralatan musik lainnya dalam kondisi baik; 9) berikan handphone sesuai indikasi; 10) pastikan bahwa volume musik adekuat dan tidak terlalu keras; 11) hindari menghidupkan musik dan dibiarkan dalam waktu yang lama; 12) fasilitasi pertisipasi aktif klien jika hal ini diinginkan klien dan sesuai dengan tempat; 13) hindari stimulasi musik setelah injuri kepala akut.

Musik Tradisional adalah musik etnis yang berasal dari tiap-tiap daerah bahkan suku, musik ini memiliki irama yang teratur sehingga bisa menciptakan relaksasi dan keadaan istirahat yang optimal (Drajat, 2017). Terapi musik tidak hanya terkait dengan bidang ilmu seperti psikologi, tetapi juga dapat dimanfaatkan dikalangan medis dan keperawatan. Terapi musik juga digunakan secara menyeluruh untuk mengatasi rasa sakit, manajemen stress atau stimulasi pertumbuhan dan perkembangan (Supriadi, 2015).

Pemilihan musik menjadi hal yang efektif untuk mengatasi kecemasan, karena musik merupakan salah satu bentuk rangsangan suara yang merupakan stimulus untuk indera pendengar. Musik dengan tempo yang lambat serta memiliki karakteristik musik yang tenang dan santai dapat menimbulkan keselarasan jiwa dan rasa (Daryani 2014). Terapi musik tradisional biasanya dilakukan selama 15 menit selama 3 kali seminggu (Putri, 2016). 
Hasil penelitian sebelumnya oleh Dewi (2010), menunjukkan bahwa ada perbedaan antara loneliness kelompok eksperimen sebelum dengan sesudah diberikan terapi musik angklung (taraf signifikasi 95\%). Hal ini menunjukkan bahwa terapi musik angklung dengan memainkan alat musik angklung secara berkelompok dapat membuat suasana hati (mood) dan kemampuan berinteraksi para subjek penelitian meningkat karena alat musik angklung memiliki unsur kenyamanan, kebahagiaan, kebersamaan dan rekreatif saat memainkannya.

Penelitian sebelumnya oleh Ariani (2012), tingkat kesepian sebelum dilakukan terapi musik angklung masuk kedalam kategori kesepian rendah dan berat, dan setelah dilakukan terapi musik angklung masuk ke dalam kategori tidak kesepian.

Hasil uji statistik menggunakan $t$ test dengan nilai $(23,773)>(2,064)$. Hal ini menunjukkan bahwa musik angklung dapat mempengaruhi tingkat kesepian pada lansia. Yudistira (2011) dalam penelitiannya menunjukkan bahwa dengan mendengarkan tembang tradisional angklung dapat menurunkan level kesepian lansia dengan spektrum frekuensi dominan $4-5 \mathrm{kHz}$ dalam durasi tengah dan 3,33-5 $\mathrm{kHz}$ dalam durasi awal dan akhir. Menurutnya, salah satu cara untuk mengurangi penghayatan perasaan kesepian (loneliness), yaitu mendengarkan musik. Musik sudah banyak diteliti dan memiliki pengaruh terhadap fungsi fisiologis dan psikologis. Musik sudah diakui dapat menjadi media dalam sebuah terapi, yang kemudian berkembang menjadi terapi musik.

Pada saat memberikan terapi musik, ada beberapa hal yang harus diperhatikan, diantaranya adalah jenis musik yang akan diberikan. Terdapat beberapa jenis musik, misalnya musik klasik, musik rock, musik gamelan, musik instrumental dan lain-lain. Kebanyakan lansia mengatakan lebih menyukai musik - musik tradisional (Hidayat, 2016). Salah satu musik tradisional yang berpengaruh dalam relaksasi adalah tradisional cina. Musik tradisional cina dikenal sebagai musik yang memiliki tempo lamban, lembut, dan juga santai, namun ada juga yang bertempo cepat sehingga dapat menimbulkan perasaan tenang dan mengurangi ketegangan otot bagi para pendengarnya dan mengurangi kesepian pada lansia (Liu, 2014). Jenis musik yang akan digunakan yaitu jenis musik yang memiliki tempo yang lambat, lembut, dan juga santai.

Berdasarkan survei awal penelitian yang dilakukan di Panti Jompo Yayasan Guna Budi Bakti Kelurahan Martubung Kecamatan Medan Labuhan Kota 
Medan, terdapat 70 orang lansia yang berumur rata- rata $\geq 60$ tahun dan semuanya bersuku cina. Saat melakukan wawancara kepada lansia di panti jompo, mereka mengatakan bahwa mereka senang mendengar musik tradisional cina dan bahasa sehari - hari mereka adalah bahasa cina. Tingkat volume untuk pendengaran lansia di panti jompo berkisar $60-70 \mathrm{~dB}$. Ketika melakukan wawancara kembali kepada 5 orang responden di Panti Jompo Yayasan Guna Budi Bakti Kelurahan Martubung Kecamatan Medan Labuhan Kota Medan Tahun 2019, 3 orang responden mengatakan bahwa tidak ada seorang pun yang dapat diandalkan atau minta tolong, mereka juga merasa terasingkan dari keluarga, 2 orang responden lainnya mengatakan bahwa banyak orang - orang atau di lingkungan panti, tetapi tetap merasa sendiri. Hasil wawancara dari salah satu perawat di panti jompo mengatakan bahwa sekitar $80 \%$ lansia belum menikah dan sangat jarang dikunjungi oleh keluarga ataupun kerabat, jadi mereka rentan mengalami kesepian. Dampak dari kesepian yang dialami oleh lansia di panti jompo adalah mereka sering merasa cemas, sering menyendiri, dan mudah bosan. Tindakan yang sering dilakukan oleh lansia untuk mengatasi kesepian yaitu membereskan barang - barang mereka ataupun tidur.
Berdasarkan uraian di atas, penulis tertarik untuk meneliti "Pengaruh Terapi Musik Tradisional Cina Terhadap Kesepian Pada Lansia di Panti Jompo Yayasan Guna Budi Bakti Kelurahan Martubung Kecamatan Medan Labuhan Kota Medan Tahun 2019

\section{METODE}

Desain penelitian yang digunakan adalah Quasi Experiment dengan metode onegroup pre and post test design. Dimana penelitian ini bertujuan untuk mengetahui pengaruh terapi musik tradisional cina terhadap kesepian pada lansia di Panti Jompo Yayasan Guna Budi Bakti. Penelitian ini dilakukan di Panti Jompo Yayasan Guna Budi Bakti Kelurahan Martubung Kecamatan Medan Labuhan Kota Medan Tahun 2019. Waktu penelitian dilaksanakan pada bulan 03 April - 03 Mei 2019

Populasi dalam penelitian ini adalah seluruh lanjut usia yang bersuku chinese sebanyak 70 orang.

Pengambilan sampel dalam penelitian ini menggunakan metode Purposive Sampling yaitu teknik pengambilan sampel sumber data dengan pertimbangan tertentu. Sampel dalam penelitian ini berjumlah sebanyak 41 orang dengan kriteria sebagai berikut: Lansia yang tinggal di panti selama $\leq 1-5$ tahun, 2) Lansia yang 
tidak memiliki masalah pendengaran, dan, 3) Lanjut usia yang dapat berkomunikasi dengan baik dan tidak sedang dalam keadaan sakit.

Aspek pengukuran yang digunakan dalam penelitian ini adalah UCLA Loneliness Scale Version 3 merupakan kuesioner untuk mengukur tingkat kesepian pada lansia.

Kusioner kesepian yang digunakan pada penelitian ini dimodifikasi dari kuesioner University California of Los Angeles (UCLA) Loneliness Scale Version 3 yang dikembangkan oleh Russel (1996) dan telah diterjemahkan ke dalam Bahasa Indonesia oleh Apriska (2016). UCLA Loneliness Scale Version 3 merupakan kuesioner untuk mengukur tingkat kesepian pada lansia.

Penelitian ini menggunakan analisis univariat untuk mengetahui karakteristik jenis kelamin, usia, agama, pendidikan, dan lama tinggal di panti responden yang mengakami kesepian di Panti Jompo Yayasan Guna Budi Bakti Kelurahan Martubung Kecamatan Medan Labuhan Kota Medan Tahun 2019.

Analisis bivariat dilakukan dengan menggunakan program statistical SPSS. Analisa dengan persamaan pre test dan post test one group design dengan $p$ value $=0,05$ dengan melakukan uji $T$ Test pada kelompok berpasangan.

\section{HASIL DAN PEMBAHASAN}

Hasil

Demografi responden dalam penelitian ini menggambarkan variabel penelitian meliputi umur, jenis kelamin, pendidikan, dan lama tinggal di panti. Adapun distribusi frekuensi responden dapat dilihat pada tabel dibawah ini:

Tabel 1

Karakteristik Responden di Panti Jompo Yayasan Guna Budi Bakti Kelurahan Martubung Kecamatan Medan Tuntungan Kota Medan tahun $2019(n=41)$

\begin{tabular}{lrr}
\hline Karakteristik & $\boldsymbol{f}$ & $\begin{array}{r}\text { Persentase } \\
(\%)\end{array}$ \\
\hline Umur & & \\
$60-70$ & 16 & 39,0 \\
$71-80$ & 16 & 39,0 \\
$81-90$ & 9 & 22,0 \\
\hline Total & 41 & 100,0 \\
\hline Jenis Kelamin & & \\
$\quad$ Laki - Laki & 17 & 41,5 \\
$\quad$ Perempuan & 24 & 58,5 \\
\hline Total & 41 & 100,0 \\
\hline Agama & & \\
Islam & 0 & 0,0 \\
Kristen & 6 & 14,6 \\
Hindu & 0 & 0,0 \\
Buddha & 35 & 85,4 \\
\hline Total & 41 & 100,0 \\
\hline Pendidikan & & \\
Tidak & & \\
Sekolah & 4 & 9,8 \\
SD & 14 & 34,1 \\
SMP & 11 & 26,8 \\
SMA & 12 & 29,3 \\
Perguruan & & \\
Tinggi & 0 & 0,0 \\
\hline Total & 41 & 100,0 \\
\hline Lama Tinggal & & \\
di Panti & & \\
$\leq 1$ tahun & 16 & 39,0 \\
2 tahun & 10 & 24,4 \\
3 tahun & 5 & 12,2 \\
4 tahun & 4 & 9,8 \\
5 tahun & 6 & 14,6 \\
\hline Total & 41 & 100,0 \\
\hline & & \\
& & \\
\hline
\end{tabular}


Berdasarkan tabel dapat diketahui bahwa mayoritas umur responden pada 60 - 70 tahun sebanyak 16 responden $(39,0 \%)$, mayoritas umur 71-80 sebanyak 16 responden $(39,0 \%)$ dan minoritas umur 81-90 sebanyak 9 responden $(22,0 \%)$.

Berdasarkan hasil penelitian, diketahui bahwa responden berjenis kelamin laki - laki sebanyak 17 responden $(41,5 \%)$ sedangkan perempuan sebanyak 24 responden $(58,5 \%)$. Diketahui bahwa responden beragama Kristen sebanyak 6 responden $(14,6 \%)$, responden beragama Buddha sebanyak 35 responden $(85,4 \%)$.

Berdasarkan hasil penelitian, diketahui bahwa pendidikan responden Tidak Sekolah sebanyak 4 responden $(9,8 \%)$, responden SD sebanyak 14 responden $(34,1 \%)$, responden SMP sebanyak 11 orang $(26,8 \%)$, dan responden SMA sebanyak 12 responden $(29,3 \%)$.

Berdasarkan hasil penelitian, diketahui bahwa lama responden tinggal dipanti $\leq 1$ tahun sebanyak 16 responden $(39,0 \%)$, selaman 2 tahun sebanyak 10 responden $(24,4 \%)$, selama 3 tahun sebanyak 5 responden $(12,2 \%)$, selama 4 tahun sebanyak 4 responden $(9,8 \%)$, dan selama 5 tahun sebanyak 6 responden $(14,6 \%)$.
Kesepian Responden Saat Sebelum (Pre Test) dan Sesudah (Post Test) Dilakukan Terapi Musik Tradisional Cina

Data yang berhubungan dengan kesepian pada lansia saat Sebelum (Pre Test) dan Sesudah (Post Test) intervensi yang ditunjukkan dalam distribusi frekuensi dan presentase, dinyatakan pada tabel dibawah ini:

Tabel 2

Distribusi Frekuensi Kesepian Responden Saat Sebelum (Pre Test) Dilakukan Terapi Musik Tradisional Cina Di Panti Jompo Yayasan Guna Budi Bakti Kelurahan Martubung Kecamatan Medan Tuntungan Kota Medan Tahun $2019(n=41)$

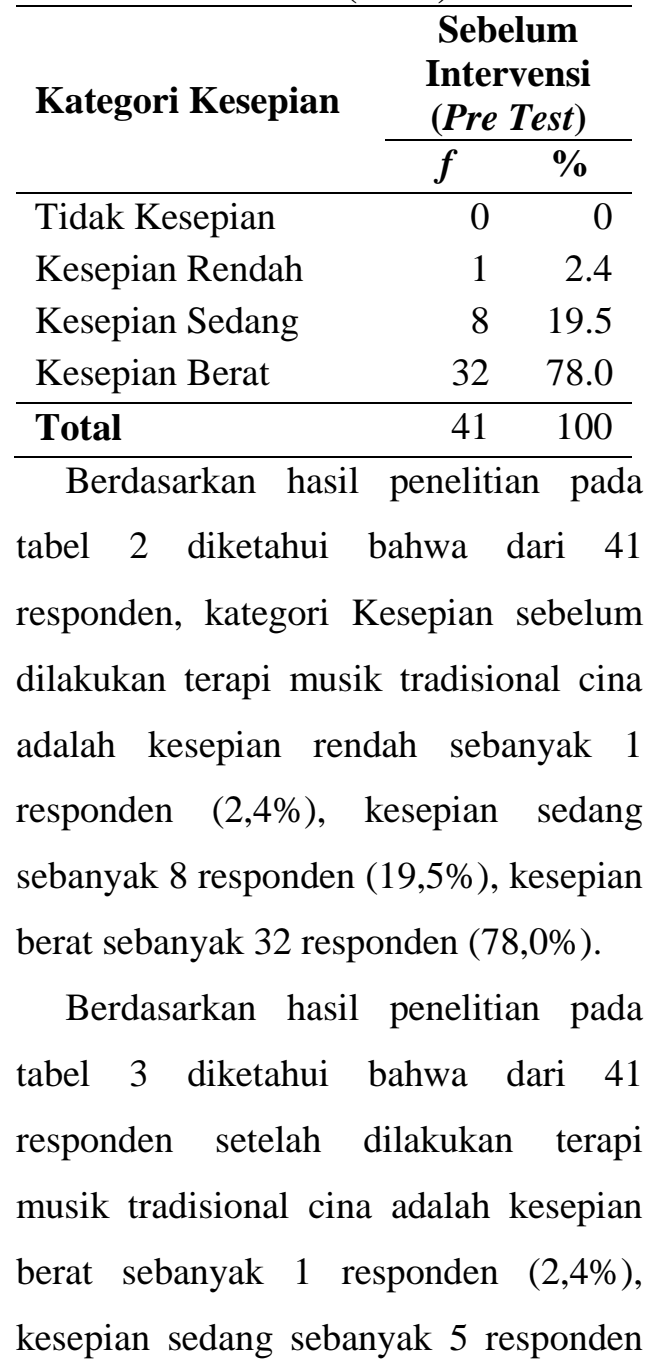


(12,2\%), kesepian rendah sebanyak 13 orang $(31,7 \%)$, tidak kesepian sebanyak 22 responden $(53,7 \%)$.

Tabel 3

Distribusi Frekuensi Kesepian Responden Saat (Post Test) Dilakukan Terapi Musik Tradisional Cina Di Panti Jompo Yayasan Guna Budi Bakti Kelurahan Martubung Kecamatan Medan Tuntungan Kota Medan Tahun 2019 (n=41)

\begin{tabular}{lrr}
\hline \multirow{2}{*}{ Kategori Kesepian } & \multicolumn{2}{l}{$\begin{array}{l}\text { Sesudah } \\
\text { Intervensi } \\
\text { (Post Test })\end{array}$} \\
\cline { 2 - 3 } & \multicolumn{1}{c}{$\boldsymbol{f}$} & \multicolumn{1}{c}{$\%$} \\
\hline Tidak Kesepian & 22 & 53.7 \\
Kesepian Rendah & 13 & 31.7 \\
Kesepian Sedang & 5 & 12.2 \\
Kesepian Berat & 1 & 2.4 \\
Total & 41 & 100 \\
\hline
\end{tabular}

Pengaruh dan Perbedaan Terapi Musik Tradisional Cina Sebelum (Pre Test) dan Sesudah (Post Test) Terhadap Kesepian

Tabel 4

Distribusi Pengaruh Terapi Musik Tradisional Cina Sebelum (Pre Test) dan Sesudah (Post Test) Terhadap Kesepian Pada Lansia di Panti Jompo Yayasan Guna Budi Bakti Kelurahan Martubung Kecamatan Medan Tuntungan Kota Medan Tahun 2019

\begin{tabular}{ccc}
\hline \multirow{2}{*}{ Variabel } & $\begin{array}{c}\text { Sebelum } \\
\text { Intervensi } \\
(\text { Pre Test })\end{array}$ & $\begin{array}{c}\text { Sesudah } \\
\text { Intervensi } \\
(\text { Post Test })\end{array}$ \\
\cline { 2 - 3 } & & (Pean
\end{tabular}

$\begin{array}{lllll}\text { Kesepian } & 66.41 & 5.45 & 36.46 & 9.917\end{array}$

Berdasarkan hasil penelitian pada tabel diatas, menunjukkan bahwa kesepian responden sebelum dilakukan intervensi dengan terapi musik tradisional cina rata - rata mencapai 66,41 dengan standar deviasi 5,54 dan sesudah dilakukan intervensi dengan terapi musik tradisional cina rata - rata mencapai 36,46 dengan standar deviasi 9,971. Menunjukkan nilai rata - rata kesepian responden sesudah dilakukan intervensi lebih rendah dari pada nilai rata-rata sebelum dilakukan intervensi sehingga dapat dinyatakan bahwa terapi musik tradisional cina memiliki pengaruh terhadap kesepian pada lansia.

Untuk mengetahui perbedaan kesepian sebelum dan sesudah intervensi pada penerapan terapi musik tradisional cina digunakan uji statistik Paired Samples T Test.

Tabel 5

Distribusi Perbedaan Kesepian Pada Lansia Sebelum (Pre Test) dan Sesudah (Post Test) di Panti Jompo Yayasan Guna Budi Bakti Kelurahan Martubung Kecamatan Medan Tuntungan Kota Medan tahun 2019 $(n=41)$

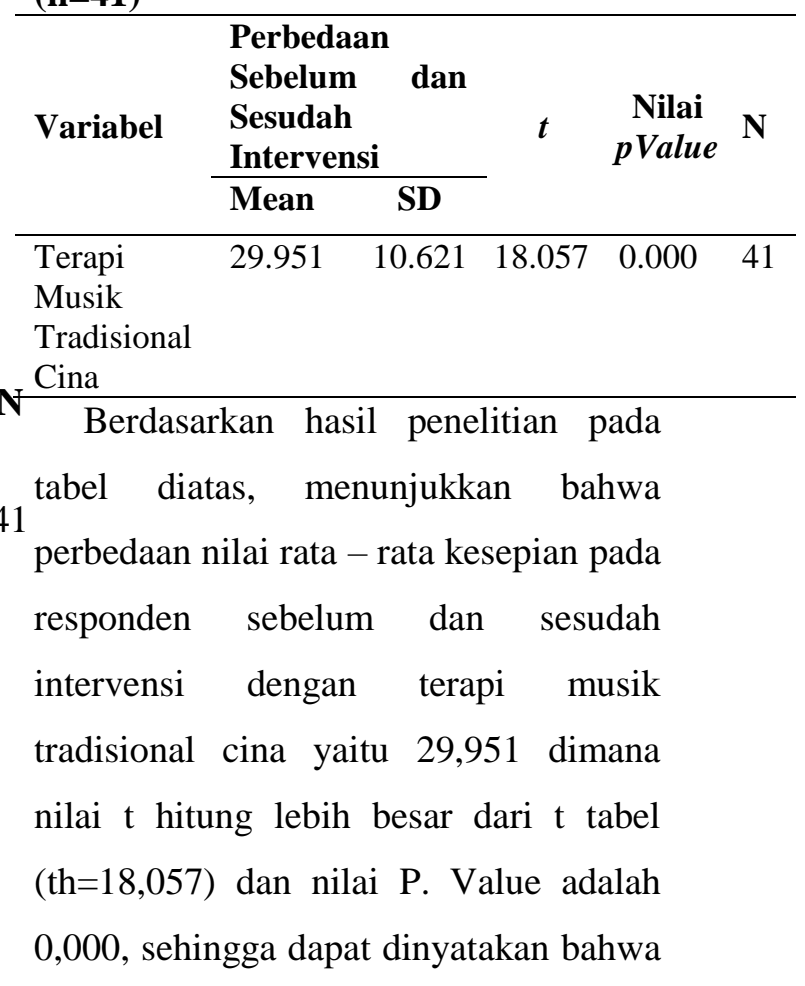


jika nilai $\mathrm{p}<0,05$ maka Ho ditolak atau ada pengaruh terapi musik tradisional cina terhadap kesepian pada lansia di Panti Jompo Yayasan Guna Budi Bakti Kelurahan Martubung Kecamatan Medan Tuntungan Kota Medan Tahun 2019.

\section{Pembahasan}

Penelitian ini membahas tentang pengaruh terapi musik tradisional cina terhadap kesepian terhadap lanjut usia di panti jompo yayasan guna budi bakti kelurahan martubung kecamatan medan labuhan kota medan tahun 2019, yang dilakukan terhadap 41 responden.

Kesepian Terhadap Lansia Sebelum (Pre Test) Dilakukan Terapi Musik Tradisional Cina

Hasil penelitian menunjukkan bahwa kesepian pada lansia Sebelum (Pre Test) Dilakukan Terapi Musik Tradisional Cina adalah kesepian rendah sebanyak 1 responden (2,4\%), kesepian sedang sebanyak 8 responden $(19,5 \%)$, kesepian berat sebanyak 32 responden $(78,0 \%)$.

Hal tersebut menunjukkan bahwa lansia mengalami kegelisahan yang dirasakan saat hubungan sosial kehilangan ciri pentingnya, baik yang bersifat menyenangkan atau tidak menyenangkan bahkan hal ini mencerminkan isolasi sosial yang dirasakan atau terbuang (Sears, dkk. 2009). Hal ini ditandai dengan perasaan terasing, tersisihkan, kurang perhatian dari orang-orang di sekitarnya, terpencil dari orang lain, merasa berbeda dengan orang lain (Suadirman, 2011). Juga ditandai dengan merasa tidak berguna atau tidak berharga, merasa gagal, dan bosan dalam menjalani hidup, merasa terpuruk, merasa sendiri atau terasing, merasa tidak ada yang mengerti, merasa tidak diperhatikan dan dicintai, serta perasaan negatif lainnya. Selain perasaan negatif tersebut, ciri - ciri lansia yang mengalami kesepian adalah kurangnya hubungan yang bermakna dengan orang lain (Rahmi, 2015).

Menurut asumsi peneliti, sebelum dilakukan terapi musik tradisional cina, responden berada pada tingkat kesepian yaitu kesepian berat sebanyak 32 responden $(78 \%)$ dari 41 responden. Ini berarti adanya perubahan kesepian yang signifikan sebelum dan sesudah dilakukannya intervensi, yakni ada pengaruh terapi musik tradisional cina terhadap kesepian terhadap lansia di Panti Jompo Yayasan Guna Budi Bakti Kelurahan Martubung Kecamatan Medan Labuhan Kota Medan Tahun 2019.

Kesepian Terhadap Lansia Sesudah (Post Test) Dilakukan Terapi Musik Tradisional Cina

Hasil penelitian menunjukkan bahwa kesepian pada lansia Sesudah (Post Test) Dilakukan Terapi Musik Tradisional Cina adalah kesepian berat 
sebanyak 1 responden (2\%), kesepian sedang sebanyak 5 responden (12\%), kesepian rendah sebanyak 13 orang (32\%), tidak kesepian sebanyak 22 responden $(54 \%)$.

Hal ini sejalan dengan penelitian yang dilakukan dewi (2010), penelitian perbandingan antara loneliness kelompok eksperimen sebelum dengan sesudah diberikan terapi musik angklung (taraf signifikasi 95\%). Hal ini menunjukkan bahwa terapi musik angklung dengan memainkan alat musik angklung secara berkelompok dapat membuat suasana hati (mood) dan kemampuan berinteraksi para subjek penelitian meningkat karena alat musik angklung memiliki unsur kenyamanan, kebahagiaan, kebersamaan dan rekreatif saat memainkannya.

Menurut Aspiani (2014), musik memiliki manfaat dalam menenangkan dan menyegarkan pikiran kembali, menumbuhkan motivasi, terjadi perkembangan kepribadian, dan dapat menjadi alat komunikasi. Terapi berkaitan dengan upaya yang dibuat untuk membantu orang dan biasanya digunakan dalam konteks masalah fisik dan mental.

Menurut asumsi peneliti sesudah dilakukan terapi musik tradisional cina responden berada pada tingkat kesepian yaitu tidak kesepian sebanyak 32 responden (78\%) dari 41 responden. Ini berarti adanya perubahan kesepian yang signifikan sebelum dan sesudah dilakukannya intervensi, yakni ada pengaruh terapi musik tradisional cina terhadap kesepian terhadap lansia di Panti Jompo Yayasan Guna Budi Bakti Kelurahan Martubung Kecamatan Medan Labuhan Kota Medan Tahun 2019.

Hal ini disebabkan karena terapi yang dilakukan 3 kali seminggu selama 30 hari kepada responden merangsang pengeluaran hormon seretonin, endhorphin, dan S-IgA sehingga menimbulkan rasa bahagia, meningkatkan sistem kekebalan tubuh serta dapat mempengaruhi penurunan tekanan darah dan menurunkan denyut jantung.

Pengaruh Terapi Musik Tradisional
Cina Terhadap Kesepian Pada Lansia
di Panti Jompo Yayasan Guna Budi
Bakti Kelurahan Martubung
Kecamatan Medan Labuhan Kota
Medan Tahun 2019
Berdasarkan uji statistik paired t-test didapatkan p.Value $=0,000<0,05$ yang berarti Ho ditolak dan Ha diterima, menunjukkan adanya pengaruh terapi musik tradisional cina terhadap kesepian terhadap lansia di Panti Jompo Yayasan Guna Budi Bakti Kelurahan Martubung Kecamatan Medan Labuhan Kota Medan Tahun 2019.

Hal ini didukung oleh penelitian yang dilakukan Ariani (2012) dengan 
judul penelitian "Pengaruh Terapi Musik Angklung Terhadap Kesepian Pada Lansia Di Rumah Perlindungan Sosial Tresna Werdha Garut" dimana dalam pnelitiannya mengatakan bahwa tingkat kesepian sebelum dilakukan terapi musik angklung masuk kedalam kategori kesepian rendah dan berat, dan setelah dilakukan terapi musik angklung masuk ke dalam kategori tidak kesepian. Hasil uji statistik menggunakan $t$ test dengan nilai $(23,773)>(2,064)$. Hal ini menunjukkan bahwa musik angklung dapat mempengaruhi tingkat kesepian pada lansia.

Hal ini didukung oleh penelitian yang dilakukan Yudistira (2011) dalam penelitiannya menunjukkan bahwa dengan mendengarkan tembang tradisional angklung dapat menurunkan level kesepian lansia dengan spektrum frekuensi dominan 4-5 kHz dalam durasi tengah dan 3,33-5 $\mathrm{kHz}$ dalam durasi awal dan akhir. Menurutnya, salah satu cara untuk mengurangi penghayatan perasaan kesepian (loneliness), yaitu mendengarkan musik. Musik sudah memiliki pengaruh terhadap fungsi fisiologis dan psikologis. Musik sudah diakui dapat menjadi media dalam sebuah terapi, yang kemudian berkembang menjadi terapi musik.

Menurut asumsi peneliti sesudah dilakukan terapi musik tradisional cina selama 30 hari (tiga kali dalam seminggu) kepada responden, kesepian responden berada pada tingkat kesepian yaitu tidak kesepian sebanyak 32 responden (78\%) dari 41 responden. Hal ini disebabkan karena terapi yang dilakukan 3 kali seminggu kepada responden yaitu merangsang pengeluaran hormon seretonin, endhorphin, dan S-IgA sehingga menimbulkan rasa bahagia, meningkatkan sistem kekebalan tubuh serta dapat mempengaruhi penurunan tekanan darah dan denyut jantung.

\section{KESIMPULAN DAN SARAN}

\section{Kesimpulan}

1. Rata - rata responden yang direkrut dalam penelitian melaporkan bahwa kesepian pada kelompok sebelum (pre test) dilakukan terapi musik tradisional cina berada pada kategori kesepian berat dengan nilai frekuensi kesepian menunjukkan bahwa dari 41 responden, kategori kesepian sebelum dilakukan terapi musik tradisional cina adalah kesepian rendah sebanyak 1 responden $(2,4 \%)$, kesepian sedang sebanyak 8 responden $(19,5 \%)$, kesepian berat sebanyak 32 responden $(78,0 \%)$.

2. Rata - rata responden yang direkrut dalam penelitian melaporkan bahwa kesepian pada kelompok sesudah (post test) dilakukan terapi musik 
tradisional cina berada pada kategori tidak kesepian dengan nilai frekuensi kesepian menunjukkan bahwa dari 41 responden, kategori kesepian sesudah dilakukan terapi musik tradisional cina adalah adalah tidak kesepian sebanyak 22 responden $(53,7 \%)$, kesepian rendah sebanyak 13 orang $(31,7 \%)$, kesepian sedang sebanyak 5 responden $(12,2 \%)$, kesepian berat sebanyak 1 responden $(2.4 \%)$.

3. Berdasarkan hasil analisa Paired Sampel T-Test pada tabel 4.3.2 menunjukan bahwa perbedaan nilai rata - rata kesepian pada responden sebelum dan sesudah intervensi dengan terapi musik tradisional cina yaitu 29,951 dimana nilai $t$ hitung lebih besar dari t tabel (th=18,057) dan nilai P. Value adalah 0,000, sehingga dapat dinyatakan bahwa jika nilai $\mathrm{p}<0,05$ maka Ho ditolak atau ada pengaruh terapi musik tradisional cina terhadap kesepian pada lansia di Panti Jompo Yayasan Guna Budi Bakti Kelurahan Martubung Kecamatan Medan Tuntungan Kota Medan Tahun 2019.

\section{Saran}

\section{Bagi Keperawatan}

Hasil penelitian dapat digunakan sebagai bahan masukan dan menambah wawasan mahasiswa dalam upaya mengatasi kesepian pada lansia dengan melakukan terapi musik tradisional cina, khususnya keperawatan gerontik.

2. Bagi Peneliti

Hasil penelitian ini diharapkan menjadi panduan bagi peneliti agar bilamana ada penelitian selanjutnya dapat dibuat lebih baik khususnya dalam ilmu keperawatan Gerontik.

\section{Bagi Lanjut Usia}

Diharapkan bagi responden agar menggunakan terapi tradisional cina, sebagai salah satu pilihan yang dapat digunakan bagi lansia untuk menangani masalah kesepian yang dihadapi.

4. Bagi Institut Kesehatan Sumatera Utara

Hasil penelitian ini diharapkan menjadi salah satu bahan masukan dalam mengembangkan ilmu keperawatan gerontik tentang pengaruh terapi musik tradisional cina terhadap kesepian pada lansia.

5. Bagi Peneliti Selanjutnya

Diharapkan kepada peneliti selanjutnya agar dapat melanjutkan penelitian ini dengan membagi jumlah sampel dalam kelompok kontrol dan kelompok intervensi sehingga data yang diperoleh lebih jelas dan akurat.

\section{DAFTAR PUSTAKA}

Apriska, R. A. D. (2016). Hubungan antara tingkat kesepian dengan mekanisme koping pada lansia di Unit Pelayanan Lanjut Usia "Wening Wardhoyo" (Skripsi). 
Semarang: Fakultas Kedokteran Universitas Diponegoro

Ariani, D. R. (2012). Pengaruh terapi musik angklung terhadap kesepian pada lansia di Rumah Perlindungan Sosial Tresna Werdha Garut. Jurnal Keperawatan, 1 (1).

Aspiani, R. Y. (2014). Buku ajar asuhan keperawatan gerontik jilid 2. Jakarta: CV TIM.

Bulechek, dkk. (2016). Nursing Interventions Classification. Indonesia: Elsevier

Daryani. (2014). Pengaruh terapi musik langgam jawa terhadap penurunan tingkat kecemasan pada lansia di purworejo. Triage Jurnal Ilmu Keperawatan (Journal of Nursing Science), 9 (1), 1 - 12.

Dewi. (2010). Rancangan terapi musik angklung untuk menurunkan penghayatan perasaan kesepian (loneliness) lansia. Tesis.

Drajat, R. S., Whardana, E. S., \& Rochmah, Y, S. (2017). Perbedaan pengaruh musik instrumental kitaro dan musik tradisional langgam jawa terhadap tingkat kecemasan anak anak sebelum tindakan perawatan gigi. Odonto Dental Journal, 4 (1), 22.

Fitriana, V. (2013). Hubungan antara tingkat kesepian dengan tingkat insomnia pada lanjut usia di Desa Srimulyo Kecamatan Piyungan Bantul Yogyakarta (Skripsi). Yogyakarta: Fakultas Kedokteran Universitas Gadjah Mada.

Gunarsa, S. D., \& Gunarsa, Y. S. D. (2009). Psikologi untuk membimbing. Jakarta: PT BPK Gunung Mulia.

Hidayat, M. F., Nahariani, P., \& Mubarrok. A. S. (2016). Pengaruh terapi musik klasik jawa terhadap penurunan tekanan darah pada sia hipertensi di UPT Panti Werdha Mojopahit Mojokerto. Jurnal Keperawatan.

Ikasi, A., Jumaini, \& Hasanah, O. (2014). Hubungan dukungan keluarga terhadap kesepian (lonelinnes) pada lansia. Jom PSIK, 1 (2).
Kementerian Kesehatan Republik Indonesia. (2015). Pelayanan dan Peningkatan Kesehatan Usia Lanjut. Jakarta: Kementerian Kesehatan Republik Indonesia.

Kementerian Kesehatan Republik Indonesia. (2017). Analisa lansia di Indonesia. Jakarta: Depkes RI

Khairani. (2014). Hubungan dukungan keluarga dengan kesepian pada lansia di Desa Cucum Kecamatan Kuta Baro Aceh Besar. Idea Nursing Journal, $V(1), 22-31$.

Lestari, D. (2014). Hubungan Dukungan Keluarga dengan Perasaan Kesepian pada Usia Lanjut di Padukuhantiwir Sumbersari Moyudan Sleman Yogyakarta.Tesis

Liu, X, dkk. (2014). Effects of fiveelement music therapy on elderly people with seasonal affective disorder in a chinese nursing home. Journal of traditional chinese medicine, 34 (2), 159-160.

Nuraini. (2018). Hubungan Interaksi Sosial dengan Kesepian pada Lansia di Kelurahan Tlogomas Kota Malang. Nursing News, 3 (1).

Putri, S. T. (2016). Differences of quality of life of ederly woman who follow brain movement exercise and angklung music therapy. Jurnal Keperawatan Sudirman, 11 (2), 108

Rahmi. (2015). Gambaran Tingkat Kesepian pada Lansia di Panti Tresna Werdha Pandaan. Seminar Psikologi \& Kemanusiaan, 257-261

Sears, D. O., Jonathan, L. F, dan L. Anne, P. (2006). Psikologi Sosial Jilid 1 Edisi Kelima. Jakarta: Erlangga.

Septiningsih, D. S., \& Tri N. (2012). Kesepian pada lanjut usia: Studi tentang bentuk, faktor pencetus dan strategi koping. Jurnal Psikologi, 11 (2), 19.

Suadirman, S. P. (2011). Psikologi lanjut usia. Yogyakarta: Gadjah Mada University Press.

Sugiyono. (2017). Metode penelitian kuantitatif, kualitatif, dan $R \& D$. Bandung: Alfabeta, CV 
Sunaryo, dkk. (2016). Asuhan keperawatan gerontik. Yogyakarta: $\mathrm{Cv}$ Andi.

Supriadi, D., Hutabarat, E., \& Monica. E. (2015). Pengaruh terapi musik tradisional kecapi suling sunda terhadap tekanan darah pada lansia dengan hipertensi. Jurnal Skolastik Keperawatan, 1 (2), 30.

Yudistira, Y., Asep A. S., \& Samsul F. A. (2011). Tembang Tradisional Angklung Untuk Mengatasi Permasalahan Psikologis Khususnya Masalah Kesepian (Loneliness) Lansia Ditinjau Dari Analisis Spektrum Frekuensi. Jurnal Penelitian Mahasiswa UNY Volume VI, Nomor 2, Agustus 2011 